\title{
Developments in Wound Dressings
}

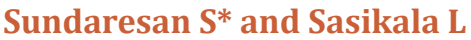 \\ Department of Fashion Technology, Sona College of Technology, India
}

Submission: September 25, 2017; Published: January 08, 2017

*Corresponding author: Sundaresan S, Department of Textile Technology, Kumaraguru College of Technology, India, Email: shobsundar@gmail.com

\section{Introduction}

Wound dressings form an important segment of wound management products. In earlier days, the dressings used for healing are of bandages and gauze with varying degrees of absorption. They were used to keep the wound bed dry and thereby making the wound as bacteria free environment. The wound treatment scenario is now totally changed, and researchers strongly feel that a warm, moist environment wounds heal so fast [1]. Introduction of newer dressings with rapid healing capability is focused on the creation of optimum healing environment. They include moist environment, circulation of oxygen and elimination of biofilms [2]. Because there exists several wound types, the dressing cannot be of similar for all wounds. Hence, for effective wound management and use of proper dressing, the knowledge on the type of the wound, healing process, and the properties of dressings are very important [3].

\section{Types of Wound Dressings}

Wound dressings are classified into the following types based on the materials used for preparation.

Traditional Dressings: Bandages and gauze made of cotton, wool or other materials are termed as traditional dressings [4]. These are dry dressings and will not create a moist environment on the wound surface. Traditional dressings are used as primary or secondary dressings based on their application and function [5]. Compression bandages can be used for lymphoedema and venous leg ulcers [6]. For packing open wounds, sterile gauze pads are used to absorb fluid and exudates. These gauze dressings should often be changed based on the amount of exudates to avoid maceration [7].

Modern Wound Dressings: Main characteristic of maintaining the moisture level is the foremost advantage of modern dressings. They also become a part of drug delivery for the healing of the wound [8].

Hydrocolloid Dressings: Due to the gel forming nature, hydrocolloids are widely used modern dressings with inherent wound healing properties. Gelatin, pectin, and carboxymethylcellulose are the gel forming agents and can be formulated as films and sheets [9]. They are used in healing of moderately exuding wounds like pressure sores, traumatic injuries, and minor burns. Due to their absorbent nature, their water vapor permeability also gets increased while forming gels. These dressings are held by an occlusive outer cover which is preventing water vapor exchange [10].

Alginate Dressings: Alginate dressings are prepared in the form of foams or fibrous sheets. Due to their higher absorbency, alginate forms gels when it is in contact with exudates. This characteristic feature makes alginate dressing minimize bacterial contamination [11]. The calcium ions present forms a cross linked polymeric gel when in contact with fluid. When it is compared with hydrocolloid dressings, alginate dressings last longer on the wound surface [12]. Human macrophages are activated to produce TNFa and, so the inflammatory signals are initiated [13]. The calcium ions released, also aids in clotting mechanism. Moderate to heavily exuding wounds can use alginate dressings. These dressings are not suitable for dry wounds covered with necrotic tissue [14].

Hydrogel Dressings: Hydrogels are hydrophilic materials, swellable and insoluble dressings. They are prepared from synthetic polymers. The form of the hydrogel dressings may be gel, film or solid sheet $[15,16]$. Significant amount of water is entrapped or absorbed by the hydrogels and retained. Hydrogel dressings are suitable for light to moderately exuding wounds. They can be used as primary or secondary wound dressings. Due to their low mechanical strength, handling becomes a tedious when it is used alone $[17,18]$.

Semi-Permeable Adhesive Film Dressings: These semipermeable dressings were initially prepared from nylon derivatives with an adhesive polyethylene support. Due to nylon, the ability of absorbing water is limited. They tend to wrinkle and become difficult to apply on the wound site. Due to their flexibility, the conformity is good, and the films are transparent. 
Extensibility, water vapor permeability and conformability differ with the material used [19].

Film Dressings: Films are semi-occlusive dressings, which can be used directly on the wound or used as a secondary dressing for a nonadhesive dressing. Hence, the exchange of water and oxygen between the outside environment and wound bed is permitted. Film dressings can be used for moderately exuding wounds to avoid fluid trapping [20].

Foam Dressings: Porous polyurethane foam or film forms foam dressings. They provide thermal insulation and maintain a moist environment. Foam dressings are highly absorbent and have a high moisture vapor transmission rate. The absorbency of foam dressings can be controlled by foam properties. They are suitable for light to moderately exuding wounds [21].

Biological Dressings: Biological dressings are prepared from biomaterials and also called as bioactive dressings. They are biodegradable and help in new tissue formation. These dressings can be incorporated with antimicrobial compounds and growth factors to be delivered at the wound site [22]. Chitosan, collagen and hyaluronic acid are also used as dressing for the delivery of drugs to the wound site [23].

\section{Conclusion}

Now the emergence of biomaterials have paved new directions in the research on wound care and wound dressing materials. It was reported that the development of dressing combined occlusion with delivery of growth factors helped to solve a specific clinical problem. It was also proposed that the occlusive dressing with angiogenic growth factor delivery is playing a vital role in the stimulation of granulation tissue to speed up epithelialization. The liquid transport and air permeability properties of needle punched nonwovens are governed by the major structural parameters such as constituent fiber properties, geometrical alignment of fiber, contact points between fibers in fabric and porosity of the fabric.

\section{References}

1. Bolton L, Van Rijswijk L (1991) Wound dressings: Meeting clinical and biological needs. Dermatol Nurs 3(3): 146-161.

2. Eaglstein WH, Davis SC, Mehle AL, Mertz PM (1988) Optimal use of an occlusive dressing to enhance healing: Effect of delayed application and early removal on wound healing. Archives of Dermatology 124(3): 392-395.

3. Armstrong DG (2009) Manuka honey improved wound healing in patients with sloughy venous leg ulcers. Evid based Med 14(5): 148.

4. Hoekstra MJ, Hermans MH, Richters CD, Dutrieux RP (2002) A histological comparison of acute inflammatory responses with a hydrofibre or tulle gauze dressing. Journal of Wound Care 11(3): 113117.
5. Jones VJ (2006) The use of gauze: Will it ever change. Int Wound J 3: 79-86.

6. Dinah F, Adhikari A (2006) Gauze packing of open surgical wounds: Empirical or evidence-based practice. Ann R Coll Surg Engl 88(1): 3336.

7. Falabella AF (2006) Debridement and wound bed preparation. Dermatol Ther 19(6): 317-325.

8. Hampton S (1999) Dressing for the occasion. Nursing Times 95: 58-60.

9. Schaller M, Laude J, Bodewaldt H, Hamm G, Korting HC (2004) Toxicity and antimicrobial activity of a hydrocolloid dressing containing silver particles in an ex vivo model of cutaneous infection. Skin Pharmacol Physiol 17(1): 31-36.

10. Thomas A, Harding KG, Moore K (2000) Alginates from wound dressings activate human macrophages to secrete tumour necrosis factor-a'. Biomaterials 21(17): 1797-1802.

11. Doyle JW, Roth TP, Smith RM, Li YQ Dunn RM (1996) Effects of calcium alginate on cellular wound healing processes modelled in-vitro. J Biomed Mater Res 32(4): 561-568.

12. Thomas S (2000) Alginate dressings in surgery and wound management-Part 1. J Wound Care 9(2): 56-60.

13. Agren MS (1996) Four alginate dressings in the treatment of partial thickness wounds: A comparative experimental study. Br J Plast Surg 49(2): 129-134.

14. Thomas A, Harding KG, Moore K (2000) Alginates from wound dressings activate human macrophages to secrete tumour necrosis factor-a. Biomaterials 21(17): 1797-1802.

15. Moody A (2006) Use of a hydrogel dressing for management of a painful leg ulcer. Br J Community Nurs 11(6): S12-S17.

16. Luo Y, Kirke KR, Prestwich GD (2000) Crosslinked hyaluronic acid hydrogel films: New biomaterials for drug delivery. J Control Release 69(1): 169-184.

17. Lay-Flurrie $\mathrm{K}$ (2004) The properties of hydrogel dressings and their impact on wound healing. Professional Nurse 19: 269-273.

18. Ueno H, Mori T, Fujinaga T (2001) Topical formulations and wound healing applications of chitosan. Adv Drug Deliv Rev 52(2): 105-115.

19. Boateng JS, Matthews KH, Stevens HNE, Eccleston GM (2008) Wound healing dressings and drug delivery systems: A review. J Pharm Sci 97(8): 2892-2923.

20. Fonder MA, Lazarus GS, Cowan DA, Aronson-Cook B, Kohli AR, et al. (2008) Treating the chronic wound: A practical approach to the care of nonhealing wounds and wound care dressings. J Am Acad Dermatol 58(2): 185-206.

21. Boateng JS, Matthews KH, Stevens HNE, Eccleston GM (2008) Wound healing dressings and drug delivery systems: a review. J Pharm Sci 97(8): 2892-2923.

22. Khan AT, Peh KK (2003) A preliminary investigation of chitosan film as dressing for punch biopsy wounds in rats. J Pharm Pharm Sci 6(1): 20-26.

23. Cho YS, Lee JW, Lee JS, Lee JH, Yoon TR, et al. (2002) Hyaluronic acid and silver sulfadiazine-impregnated polyurethane foams for wound dressing application. J Mater Sci Mater Med 13(9): 861-865. 
CC This work is licensed under Creative

DOI: 10.19080/CTFTTE.2018.02.555578
Your next submission with Juniper Publishers will reach you the below assets

- Quality Editorial service

- Swift Peer Review

- Reprints availability

E-prints Service

- Manuscript Podcast for convenient understanding

- Global attainment for your research

- Manuscript accessibility in different formats

( Pdf, E-pub, Full Text, Audio)

- Unceasing customer service

Track the below URL for one-step submission https://juniperpublishers.com/online-submission.php 